\title{
A comparative study of four rod load reduction techniques for deep-rod pumping
}

\author{
Yi Zuo ${ }^{1}$ (D) Xiaodong $\mathrm{Wu}^{1}$
}

Received: 7 March 2017/ Accepted: 17 June 2017/Published online: 27 June 2017

(c) The Author(s) 2017. This article is an open access publication

\begin{abstract}
In deep-rod pumping wells, polished rod load tends to be very high and even exceeds the operating range of the pumping unit. To tackle the problem, mainly four rod load reduction techniques have been designed till now. They are side-flow pump, rod load reducer, fiberglass sucker rod and deep pumping with small-diameter pump. However, some of them still cause certain problems when put into use. That indicates the fundamental mechanisms of these techniques have not yet been fully studied. In this paper, on the basis of conventional polished rod load calculation models, the new calculation models for these techniques are respectively established. The rod load reduction effects are comparatively analyzed by calculation. The results indicate that the differences in mechanisms lead to different reduction effects. Side-flow pump and deep pumping with small-diameter pump can largely reduce the liquid pressure load, but its reduction effect for the polished rod load is very limited. On the contrary, fiberglass sucker rod can greatly reduce the polished rod load by decreasing the weight of the sucker rod. Rod load reducer does not change the previous load; instead, it can create an additional reduction force. The potential disadvantages are also discussed. When using a side-flow pump, the resistance on the plunger caused by the liquid pressure would increase. This resistance may cause the sucker rod to bend when it is moving downwards. Deep pumping with small-diameter pump needs to use very small pump in order to get a relatively good reduction effect, so its application is limited. These disadvantages should be considered in practical application.
\end{abstract}

Yi Zuo

ayxkzy@163.com

1 China University of Petroleum, Beijing, China
Keywords Deep-rod pumping · Polished rod load · Load reduction $\cdot$ Side-flow pump

\section{Introduction}

Sucker rod pumping is a traditional and widely used method of artificial lifting in the world's oil industry. In recent years, on the one hand, as the natural energy has been depleted and working fluid level is going down, most of old oilfields in the late development stage need deep pumping techniques to increase oil production; on the other hand, deep reservoirs are gradually being developed. For example, the average reservoir depth in Tahe oilfield of Northwest China is more than $6000 \mathrm{~m}$. With the complex geological conditions and bad fluid properties, the working fluid level is very low and rapidly dropping to the limit depth of conventional sucker rod pumping system. The limit depth mainly depends on the polished rod load which increases with the pump depth. However, high polished rod load is disadvantageous to the whole system and even tends to exceed the operating range of the pumping unit. At present, aiming at the problem about how to reduce the polished rod load in the deep sucker rod pumping wells, mainly four rod load reduction techniques have been designed. They are side-flow pump, rod load reducer, fiberglass-steel sucker rod and deep pumping with smalldiameter pump.

The side-flow pump has a special structure. It uses solid plunger instead of hollow plunger, and its traveling valve is substituted by side-flow valve (Zhao and Liu 2009). Compared with the conventional pump, this pump can cause a smaller polished rod load; thus, a deeper pump depth can be achieved. 
The rod load reducer is a device installed at certain depth between the well head and the pump. With dual plungers, it can produce a hydraulic feedback force to reduce the polished rod load (Meng et al. 2002).

In contrast to steel sucker rod with relatively heavy weight, fiberglass sucker rod is much lighter. So it can reduce the polished rod load (Hicks 1986). Considering that fiberglass sucker rod cannot bear compressive stress, a length of steel sucker rod is needed to be connected to the bottom of the fiberglass sucker rod.

Deep pumping with small-diameter pump is aimed to solve the problem in old oilfields at their late development stage (Feng 1990). With the existing pumping units, using small-diameter pump can reduce liquid pressure load which is a part of the polished rod load. Therefore, the pump depth can be deepened. That helps to improve the pump efficiency.

The rod load reduction effects of the four techniques have been proved by applications on the fields. However, some of them still cause certain problems when put into use. That indicates the fundamental mechanisms of these techniques have not yet been fully studied. Moreover, the four techniques have not been compared with each other before. In the following section, on the basis of conventional polished rod load calculation, the polished rod load calculation models for these techniques are respectively established. The rod load reduction effects are comparatively analyzed by calculation. From the result, the mechanisms of rod load reduction are figured out and the potential disadvantages are discussed.

\section{Conventional polished rod load calculation model}

Polished rod load includes static load and dynamic load. Static load includes the sucker rod gravity load and liquid pressure load. And dynamic load is mainly comprised of vibration load, inertial load and friction load. The API RP 11L method (API 1977) is adopted to calculate the polished rod load in this paper. Compared with other simplified models, the calculation model in API RP 11L method takes into account both static load and dynamic load, so it is more precise and reliable. API RP 11L method has been widely used in the global petroleum industry. Considering that the specific calculation formulas for the static load are not given in API RP 11L method, we only listed them in detail and the dynamic load can be calculated according to API RP 11L method.

For a conventional pump system, the maximum and minimum polished rod load can be estimated by the following model based on API RP 11L method.

\section{Maximum polished rod load}

The maximum polished rod load happens in upstroke. The maximum polished rod load is

$P_{\max }=W_{\mathrm{r}}+W_{1}+P_{\mathrm{du}}$

In upstroke, sucker rod gravity load is

$W_{\mathrm{r}}=\rho_{\mathrm{s}} g f_{\mathrm{r}} h_{\mathrm{p}}$

Liquid pressure load is

$W_{1}=\rho_{1} g\left(f_{\mathrm{p}}-f_{\mathrm{r}}\right) h_{\mathrm{p}}-\rho_{1} g f_{\mathrm{p}}\left(h_{\mathrm{p}}-h_{\mathrm{d}}\right)$

\section{Minimum polished rod load}

The minimum polished rod load happens in downstroke. The minimum polished rod load is

$P_{\text {min }}=W_{\mathrm{r}}+W_{1}-P_{\mathrm{dd}}$

In downstroke, sucker rod gravity load is

$W_{\mathrm{r}}=\rho_{\mathrm{s}} g f_{\mathrm{r}} h_{\mathrm{p}}$

Liquid pressure load is

$W_{1}=-\rho_{1} g f_{\mathrm{r}} h_{\mathrm{p}}$

where $\rho_{\mathrm{s}}$ is the density of the sucker rod, $\mathrm{kg} / \mathrm{m}^{3} ; f_{\mathrm{r}}$ is the cross-sectional area of the sucker rod, $\mathrm{m}^{2} ; f_{\mathrm{p}}$ is the crosssectional area of the pump, $\mathrm{m}^{2} ; h_{\mathrm{p}}$ is the depth of the pump, $\mathrm{m} ; h_{\mathrm{d}}$ is the depth of the working fluid level, $\mathrm{m} ; \rho_{1}$ is the density of the liquid in well, $\mathrm{kg} / \mathrm{m}^{3} ; W_{\mathrm{r}}$ is the sucker rod gravity load, $\mathrm{N} ; W_{1}$ is the liquid pressure load, $\mathrm{N} ; P_{\mathrm{du}}$ is the maximum dynamic load in upstroke, $\mathrm{N} ; P_{\mathrm{dd}}$ is the maximum dynamic load in downstroke, $\mathrm{N}$.

\section{Side-flow pump}

As shown in Fig. 1, the side-flow pump is made up of two solid plungers with different diameters and two pump barrels with different internal diameters (Luan et al. 2011). The lower pump barrel and the tubing casing annulus are connected by the breathing hole. Compared with a conventional pump, the side-flow pump makes use of solid plungers instead of hollow plunger and replaces the traveling valve with a side-flow valve.

In the conventional pump system, the standing valve closes and fluid in the pump barrel pushes the traveling valve open and flows into the tubing in downstroke. In upstroke, with the traveling valve closed, the rod string lifts the weight of fluid in the tubing. However, the side-flow pump works differently. In upstroke, the side-flow valve closes and the standing valve opens. Formation fluid flows into the lower pump barrel below the lower plunger. Unlike the conventional pump, little fluid is lifted, so the polished 
Fig. 1 Structure of side-flow pump

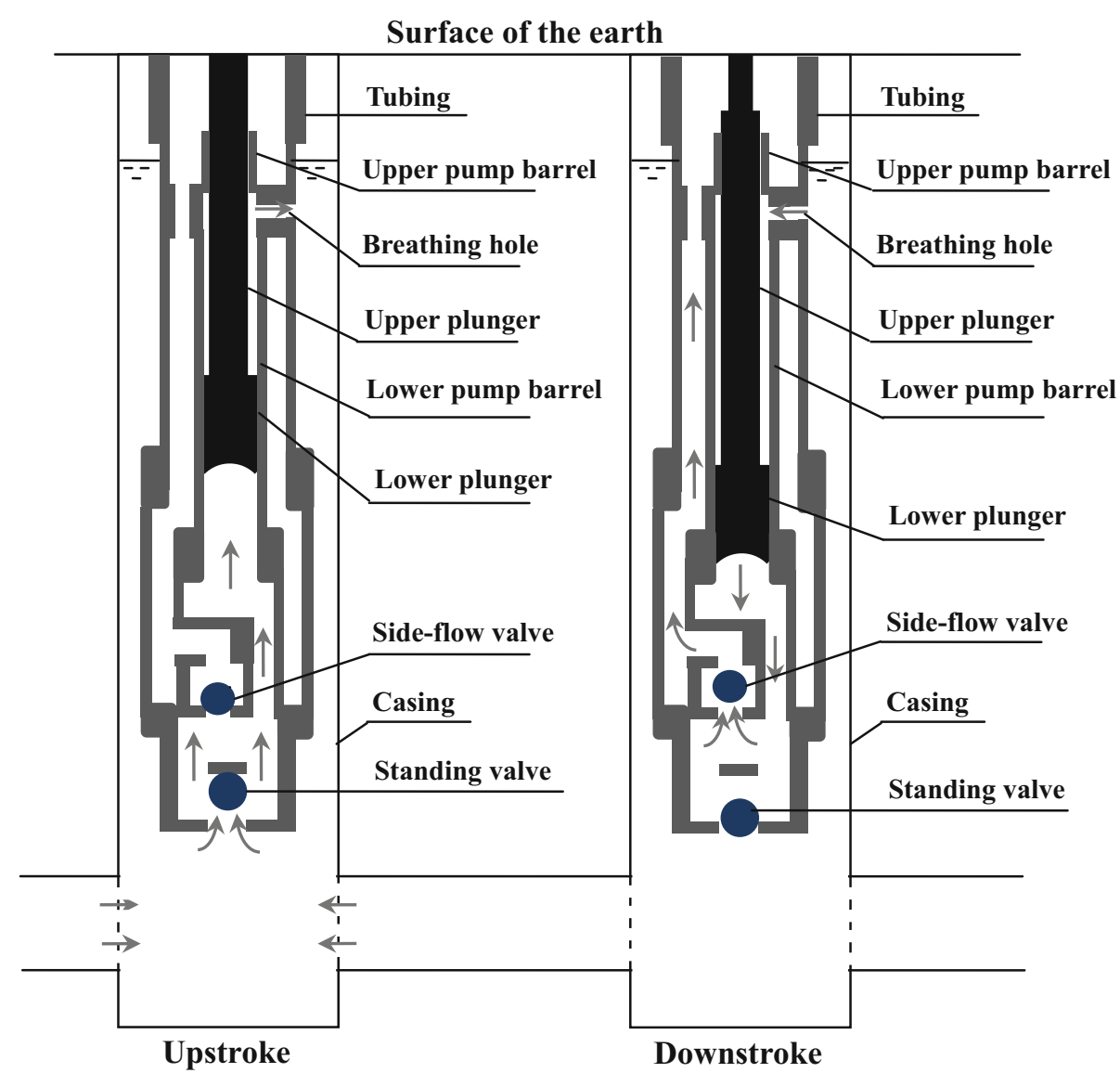

rod mainly bears the weight of the sucker rod string during the upstroke. In downstroke, the standing valve closes. The fluid in the lower pump barrel below the lower plunger, which is compressed by the falling plunger, pushes the side-flow valve open and flows into the tubing. Therefore, the side-flow pump mainly produces fluid in downstroke, which is contrary to a conventional pump.

From the detailed analysis of above working principle and following force condition, it can be found that the sideflow pump actually reduces the liquid pressure load in both upstroke and downstroke, thus decreasing polished rod load.

\section{Force analysis of side-flow pump}

Due to its special structure, the force condition of the sideflow pump is different from that of the conventional pump. When the sucker rod pumping system works, the sucker rod connected to the polished rod performs vertical reciprocating motion. Thus, we choose the sucker rod and plungers as the object of the force analysis. The result is shown in Fig. 2.

In this figure, $W_{\mathrm{r}}$ is the gravity load of sucker rod, $F_{1}$ is the liquid pressure load acting on the top surface of the upper plunger, $F_{2}$ is the liquid pressure load acting on the top surface of the lower plunger, $F_{3}$ is the liquid pressure load acting on the bottom surface of the lower plunger in upstroke, $F_{4}$ is the liquid pressure load acting on the bottom surface of the lower plunger in downstroke, $P_{\mathrm{du}}$ is the dynamic load in upstroke, and $P_{\mathrm{dd}}$ is the dynamic load in downstroke.

\section{Polished rod load calculation model}

Due to its unique structure, the force condition of side-flow pump is more complex than the conventional pump, so we need to modify the calculation model. The specific calculation formulas for the static load are listed below, and the dynamic load is changed accordingly.

\section{Sucker rod gravity load}

Sucker rod gravity load is constant in both upstroke and downstroke, which can be described by the following formula,

$W_{\mathrm{r}}=f_{\mathrm{r}} \rho_{\mathrm{s}} g h_{\mathrm{p}}$

\section{Liquid pressure load}

The liquid pressure load consists of several forces, which can be calculated by the following formulas 
Fig. 2 Force analysis of sideflow pump

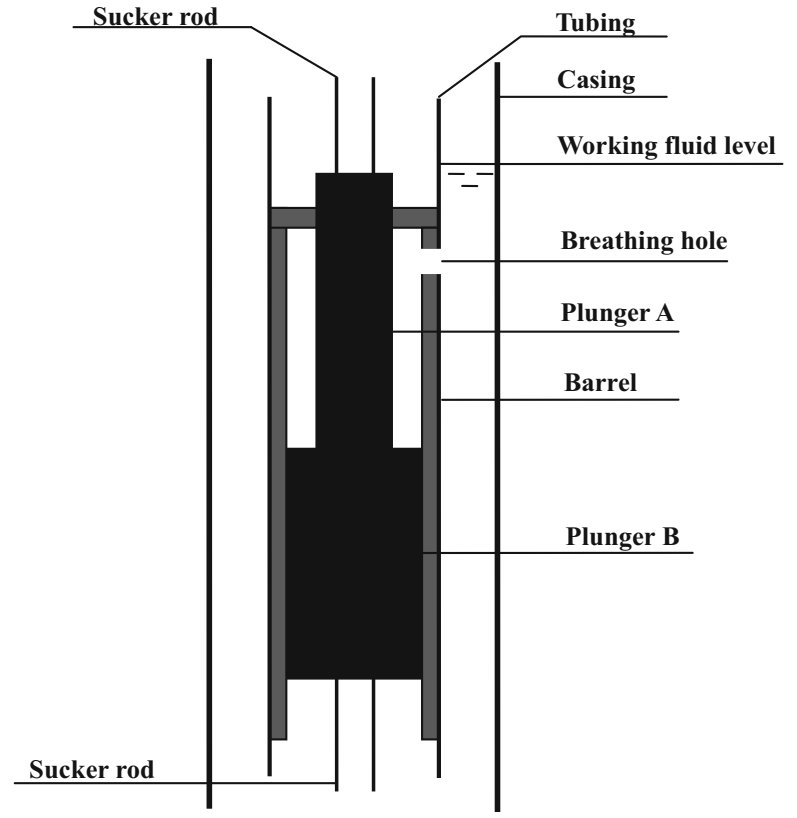

Fig. 3 Structure of rod load reducer

$$
\begin{aligned}
& F_{1}=\rho_{1} g h_{\mathrm{p}}\left(A_{1}-f_{\mathrm{r}}\right) \\
& F_{2}=\left[P_{\mathrm{c}}+\rho_{1} g\left(h_{\mathrm{p}}-h_{\mathrm{d}}\right)\right]\left(A_{2}-A_{1}\right) \\
& F_{3}=-\left[P_{\mathrm{c}}+\rho_{1} g\left(h_{\mathrm{p}}-h_{\mathrm{d}}\right)\right] A_{2} \\
& F_{4}=-\rho_{1} g h_{\mathrm{p}}
\end{aligned}
$$

where $A_{1}$ is the cross-sectional area of the upper plunger, $\mathrm{m}^{2} ; A_{2}$ is the cross-sectional area of the lower plunger, $\mathrm{m}^{2}$; $P_{\mathrm{c}}$ is the casing pressure, $\mathrm{Pa}$.

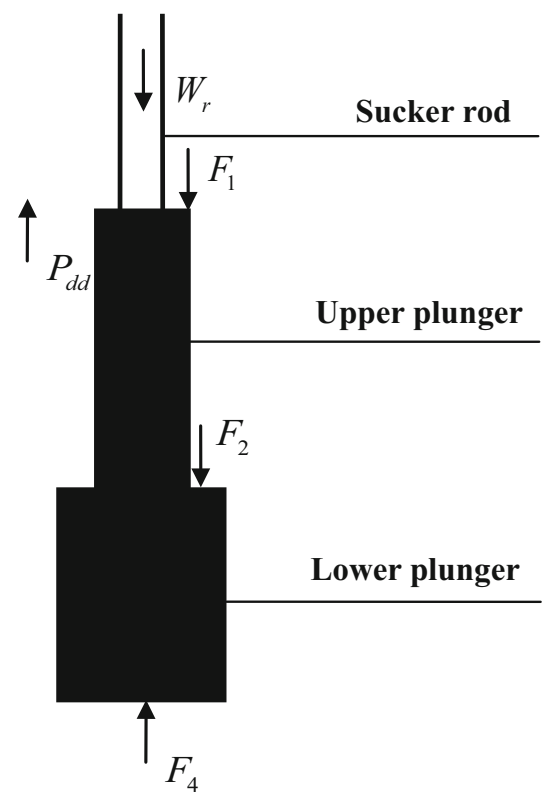

Downstroke

Upstroke

Maximum polished rod load

If we neglect the casing pressure, then

$P_{\max }=W_{\mathrm{r}}+F_{1}+F_{2}-F_{3}+P_{\mathrm{du}}$

$P_{\text {max }}=f_{\mathrm{r}} \rho_{\mathrm{s}} g h_{\mathrm{p}}-\rho_{\mathrm{l}} g h_{\mathrm{p}} f_{\mathrm{r}}+\rho_{\mathrm{l}} g h_{\mathrm{d}} A_{1}+P_{\mathrm{du}}$

Minimum polished rod load

If we neglect the casing pressure, then

$P_{\min }=W_{\mathrm{r}}+F_{1}+F_{2}-F_{4}-P_{\mathrm{dd}}$

$P_{\min }=f_{\mathrm{r}} \rho_{\mathrm{s}} g h_{\mathrm{p}}-\rho_{1} g h_{\mathrm{p}} f_{\mathrm{r}}-\rho_{1} g h_{\mathrm{d}}\left(A_{2}-A_{1}\right)-P_{\mathrm{dd}}$

\section{Calculation of load reduction}

Using the model, we calculate the polished rod load of the side-flow pump system and then compare it with that of the conventional pump system.

The basic data of well $\mathrm{X}$ we study are shown in Table 1 .

Table 2 shows the calculation result including sucker rod gravity load, liquid pressure load, maximum and minimum polished rod load of the side-flow pump system and conventional pump system. The result indicates that the side-flow pump mainly alters the liquid pressure load. Compared with the conventional pump system, the liquid pressure load in side-flow pump system decreases by $8931.3 \mathrm{~N}$ in both upstroke and downstroke. Though this $8931.3 \mathrm{~N}$ force occupies a big part of the liquid pressure load, it actually does not have a big effect on the polished rod load which only decreases by around $4 \%$. 
Table 1 Basic data of well X

\begin{tabular}{|c|c|c|c|}
\hline Parameter & Value & Parameter & Value \\
\hline Depth of pump/m & 4650 & Diameter of side-flow pump' s lower plunger $/ \mathrm{mm}$ & 38 \\
\hline Depth of working fluid level/m & 3000 & Diameter of side-flow pump' s upper plunger $/ \mathrm{mm}$ & 32 \\
\hline Liquid density $/\left(\mathrm{kg} / \mathrm{m}^{3}\right)$ & 920 & Diameter of conventional pump/mm & 38 \\
\hline Sucker rod density $/\left(\mathrm{kg} / \mathrm{m}^{3}\right)$ & 7850 & Gravitational acceleration/(N/kg) & 9.81 \\
\hline Pumping speed/(/min) & 3 & Elastic modulus of fiberglass $/ \mathrm{Pa}$ & $4.96 \times 10^{10}$ \\
\hline Stroke/m & 7.5 & Elastic modulus of steel/Pa & $2.06 \times 10^{11}$ \\
\hline Sucker rod combination & \multicolumn{3}{|c|}{$\begin{array}{l}1500 \mathrm{~m} \text { of } 29 \mathrm{~mm} \text { steel sucker rod }+1200 \mathrm{~m} \text { of } 25 \mathrm{~mm} \text { steel sucker rod }+1200 \mathrm{~m} \text { of } 22 \mathrm{~mm} \text { steel sucker } \\
\text { rod }+750 \mathrm{~m} \text { of } 38 \mathrm{~mm} \text { steel sucker rod }\end{array}$} \\
\hline
\end{tabular}

Table 2 Result of polished rod load calculation—side-flow pump

\begin{tabular}{|c|c|c|c|c|c|c|c|c|}
\hline & \multicolumn{4}{|l|}{ Upstroke } & \multicolumn{4}{|l|}{ Downstroke } \\
\hline & $\begin{array}{l}\text { Sucker rod } \\
\text { gravity load/N }\end{array}$ & $\begin{array}{l}\text { Liquid } \\
\text { pressure } \\
\text { load/N }\end{array}$ & $\begin{array}{l}\text { Dynamic } \\
\text { load/N }\end{array}$ & $\begin{array}{l}\text { Maximum } \\
\text { polished rod load/ } \\
\mathrm{N}\end{array}$ & $\begin{array}{l}\text { Sucker rod } \\
\text { gravity load/N }\end{array}$ & $\begin{array}{l}\text { Liquid } \\
\text { pressure } \\
\text { load/N }\end{array}$ & $\begin{array}{l}\text { Dynamic } \\
\text { load/N }\end{array}$ & $\begin{array}{l}\text { Minimum } \\
\text { polished rod load/ } \\
\mathrm{N}\end{array}$ \\
\hline $\begin{array}{l}\text { Conventional } \\
\text { pump system }\end{array}$ & $222,290.5$ & $14,753.7$ & $20,857.0$ & $257,901.3$ & $222,290.5$ & $-15,953.1$ & $-17,531.7$ & $188,805.7$ \\
\hline $\begin{array}{l}\text { Side-flow pump } \\
\text { system }\end{array}$ & $222,290.5$ & 5822.4 & $20,857.0$ & $248,969.9$ & $222,290.5$ & $-24,884.4$ & $-17,531.7$ & $179,874.4$ \\
\hline Reduction & 0 & 8931.3 & 0 & 8931.3 & 0 & 8931.3 & 0 & 8931.3 \\
\hline Reduction rate & 0 & $60.5 \%$ & 0 & $3.5 \%$ & 0 & $56.0 \%$ & 0 & $4.7 \%$ \\
\hline
\end{tabular}

\section{Rod load reducer}

Rod load reducer is a downhole device installed at certain depth between the well head and the pump. With dual solid plungers, it can produce a hydraulic feedback force to reduce the polished rod load. As shown in Fig. 3, a rod load reducer comprises dual plungers, a barrel and some small components. There is channel in dual plungers so that the fluid can pass through the device.

Due to the existence of the breathing hole, the upper surface of the plunger B is at the same pressure system with the liquid in casing annulus, while the lower surface of the plunger B is at the same pressure system with the liquid in tubing. Therefore, the pressure difference creates a force to reduce the polished rod load.

\section{Force analysis of rod load reducer}

We choose the sucker rod and plungers as the object of the force analysis. According to the place of working liquid level, two conditions should be analyzed. The result is shown in Fig. 4. In this figure, $F_{1}$ is the liquid pressure force acting on the bottom surface of the Plunger $\mathrm{B}, F_{2}$ is the liquid pressure force acting on the top surface of the
Plunger $\mathrm{B}, F_{3}$ is the liquid pressure force acting on the top surface of the Plunger A.

\section{Polished rod load calculation model}

Rod load reducer is a device installed on the sucker rod, so instead of changing the pump's structure, it just creates an additional force to counteract a part of the polished rod load. Therefore, we just need to analyze the reduction force and then add it to the conventional polished rod load calculation model. In this case, the casing pressure is neglected.

Working liquid level above breathing hole

$$
\begin{aligned}
F & =F_{1}-F_{2}-F_{3} \\
& =\rho_{1} g h_{\mathrm{r}}\left(A_{2}-f_{\mathrm{r}}\right)-\rho_{l} g\left(h_{\mathrm{r}}-h_{\mathrm{d}}\right)\left(A_{2}-A_{1}\right)-\rho_{1} g h_{\mathrm{r}}\left(A_{1}-f_{\mathrm{r}}\right) \\
& =\rho_{1} g h_{\mathrm{d}}\left(A_{2}-A_{1}\right)
\end{aligned}
$$

where $A_{1}$ is the cross-sectional area of Plunger $\mathrm{A}, \mathrm{m}^{2} ; A_{2}$ is the cross-sectional area of the Plunger $\mathrm{B}, \mathrm{m}^{2} ; h_{r}$ is the 
depth of the rod load reducer, $\mathrm{m} ; F$ is the reduction force, $\mathrm{N}$.

\section{Working liquid level below breathing hole}

As the casing pressure is neglected, $F_{2}$ equals to zero in this condition.

$$
\begin{aligned}
F & =F_{1}-F_{3} \\
& =\rho_{1} g h_{\mathrm{r}}\left(A_{2}-f_{\mathrm{r}}\right)-\rho_{1} g h_{\mathrm{r}}\left(A_{1}-f_{\mathrm{r}}\right) \\
& =\rho_{1} g h_{\mathrm{r}}\left(A_{2}-A_{1}\right)
\end{aligned}
$$

\section{Calculation of load reduction}

Using the model, we calculate the polished rod load of the pumping system installed a rod load reducer and then compare it with that of the conventional pump system.

Still take well $\mathrm{X}$ as an example. This time the conventional pump with a diameter of $38 \mathrm{~mm}$ is used and a rod load reducer is installed at the depth of $2000 \mathrm{~m}$. The basic data for rod load reducer are shown in Table 3.

The results are shown in Table 4. From the results we can see that after a rod load reducer is installed in the well, both maximum polished rod load and minimum polished rod load are reduced by around $20 \%$.

\section{Fiberglass sucker rod}

Development of fiberglass sucker rod for use in sucker rod pumping oil wells was started in 1973, based on the need for a sucker rod that could pump under highly corrosive and heavily loaded condition (Saul III and Detterick 1980). In contrast to standard steel sucker rod with relatively heavy weight, fiberglass sucker rod bodies are much lighter. That is because fiberglass has a low density. Thus, using fiberglass sucker rod can significantly reduce the gravity load acting on the polished rod.

However, relatively heavy, stiff steel sucker rod must be run on the bottom of the fiberglass sucker rod interval, because fiberglass sucker rod is weak when loaded in compression. If the fiberglass sucker rod is subjected to compression, the rod string body could be crushed beneath the wedges and a pullout failure could occur (Gibbs 1991).

Carbon fiber sucker rod and wire rope sucker rod are also lightweight sucker rod; however, their application is limited compared with the fiberglass sucker rod. So we chose fiberglass sucker rod as a representative technique to study. The research of wire rope sucker rod started in 1960s. Some field tests showed that it could greatly reduce the polished rod load and energy consumption (Tan and Zhang 2005); however, it is rarely used in fields and seen in the studies nowadays. Carbon fiber sucker rod seems to be a potential technique to resolve some problems for deeprod pumping, though it is not used as commonly as fiberglass sucker rod. Xinjiang oilfield in China has started to conduct the field test recently, and carbon fiber sucker rod shows good performance (Zhao et al. 2016).

\section{Calculation of load reduction}

Because using fiberglass sucker rod does not change the structure of the pumping system, we do not need to conduct force analysis as we have done on the former two technologies. We can use the conventional model to calculate the polished rod load; however, it should be noted that the formulas for calculating the natural frequency and the elastic modulus of the composite sucker rod are more complex compared with the all steel sucker rod (Li 1991).

Still take well $\mathrm{X}$ as an example. This time we use conventional pump with a diameter of $38 \mathrm{~mm}$. The all steel sucker rod string and fiberglass-steel composite sucker rod string have been respectively designed. The basic data of

Table 3 Basic data of rod load reducer

\begin{tabular}{llll}
\hline Parameter & Value & Parameter & Value \\
\hline Depth of rod load reducer/m & 2000 & Diameter of plunger A/mm & 44 \\
Depth of working fluid level/m & 3000 & Diameter of plunger B/mm & 70 \\
\hline
\end{tabular}

Table 4 Result of polished rod load calculation—rod load reducer

\begin{tabular}{lccc}
\hline & Maximum polished rod load/N & Minimum polished rod load/N & Reduction force/N \\
\hline Without a rod load reducer & $257,901.3$ & $188,805.8$ \\
With a rod load reducer & $215,881.4$ & $146,785.9$ & $42,019.9$ \\
Reduction & $42,019.9$ & $42,019.9$ & $22.3 \%$ \\
Reduction rate & $16.3 \%$ & & \\
\hline
\end{tabular}


Table 5 Sucker rod combination

\begin{tabular}{lc}
\hline & Sucker rod combination \\
\hline All steel sucker rod & $\begin{array}{c}1500 \mathrm{~m} \text { of } 29 \mathrm{~mm} \text { steel sucker rod }+1200 \mathrm{~m} \text { of } 25 \mathrm{~mm} \text { steel sucker rod }+1200 \mathrm{~m} \text { of } 22 \mathrm{~mm} \text { steel sucker } \\
\text { rod }+750 \mathrm{~m} \text { of } 38 \mathrm{~mm} \text { steel sucker rod }\end{array}$ \\
$\begin{array}{l}1500 \mathrm{~m} \text { of } 29 \mathrm{~mm} \text { fiberglass sucker rod }+1200 \mathrm{~m} \text { of } 25 \mathrm{~mm} \text { fiberglass sucker rod }+1200 \mathrm{~m} \text { of } 22 \mathrm{~mm} \\
\text { fiberglass-steel composite } \\
\text { sucker rod }\end{array}$ & \begin{tabular}{l} 
fibers sucker rod $+750 \mathrm{~m}$ of $38 \mathrm{~mm}$ steel sucker rod \\
\hline
\end{tabular}
\end{tabular}

Table 6 Result of polished rod load calculation-fiberglass sucker rod

\begin{tabular}{|c|c|c|c|c|c|c|c|c|}
\hline & \multicolumn{4}{|l|}{ Upstroke } & \multicolumn{4}{|l|}{ Downstroke } \\
\hline & $\begin{array}{l}\text { Sucker rod } \\
\text { gravity load/ } \\
\mathrm{N}\end{array}$ & $\begin{array}{l}\text { Liquid } \\
\text { pressure } \\
\text { load/N }\end{array}$ & $\begin{array}{l}\text { Dynamic } \\
\text { load/N }\end{array}$ & $\begin{array}{l}\text { Maximum } \\
\text { polished rod } \\
\text { load/N }\end{array}$ & $\begin{array}{l}\text { Sucker rod } \\
\text { gravity load/ } \\
\mathrm{N}\end{array}$ & $\begin{array}{l}\text { Liquid } \\
\text { pressure } \\
\text { load/N }\end{array}$ & $\begin{array}{l}\text { Dynamic } \\
\text { load/N }\end{array}$ & $\begin{array}{l}\text { Minimum } \\
\text { polished rod } \\
\text { load/N }\end{array}$ \\
\hline All steel sucker rod & $222,290.5$ & $14,753.7$ & $20,857.0$ & $257,901.3$ & $222,290.5$ & $-15,953.1$ & $-17,531.7$ & $188,805.7$ \\
\hline $\begin{array}{l}\text { Fiberglass-steel } \\
\text { composite sucker } \\
\text { rod }\end{array}$ & $106,247.3$ & $14,753.7$ & $10,978.6$ & $131,979.6$ & $106,247.3$ & $-15,953.1$ & $-11,579.3$ & $78,714.9$ \\
\hline Reduction & $116,043.2$ & 0 & 9878.4 & $125,921.7$ & $116,043.2$ & 0 & -5952.4 & $110,090.8$ \\
\hline Reduction rate & $52.2 \%$ & 0 & $47.4 \%$ & $49.0 \%$ & $52.2 \%$ & 0 & $-34.0 \%$ & $58.3 \%$ \\
\hline
\end{tabular}

the well are shown in Table 1, and the sucker rod combination is shown in Table 5.

From the results in Table 6, we can see that using fiberglass-steel composite sucker rod can largely reduce the polished rod load by around $50 \%$ in whole stroke compared with using all steel sucker rod. Fiberglass sucker rod does not change the liquid pressure load, while it can reduce sucker rod gravity load to a great extent. When the depth of pump is deeper and the proportion of fiberglass sucker rod is higher, the reduction effect will be better.

\section{Deep pumping with small-diameter pump}

Deep pumping with small-diameter pump means to use small-diameter pump in place of bigger-diameter pump to deepen the pump. Small-diameter pump has a relatively smaller cross-sectional area, so the liquid pressure load can be reduced.

\section{Calculation of load reduction}

Deep pumping with small-diameter pump, which is similar to fiberglass sucker rod, also does not change the structure of the pumping system, so the model we use is the same.

Still take well $\mathrm{X}$ as an example. This time we use two conventional pumps with a diameter of 56 and $38 \mathrm{~mm}$ separately in order to get a better comparison.

The results are shown in Table 7 .
From the results, we can see that using a pump with a small diameter only decreases the liquid pressure load. Therefore, only maximum polished rod load is reduced by $11.3 \%$. The reduction effect depends on the diameter of the pump.

\section{Comparative analysis}

After these four rod load reduction techniques are studied separately above, the comparative analysis is conducted in this section.

The mechanisms of these techniques are different. Sideflow pump mainly reduces the liquid pressure load by changing the structure of the conventional pump. Deep pumping with small-diameter pump also reduces the liquid pressure load by decreasing the cross-sectional area of the plunger in the pump. Fiberglass sucker rod mainly reduces the sucker rod gravity load because of its low density. However, rod load reducer, which is very different from the above three techniques, does not change the previous load; instead, it can create an additional reduction force to counteract a part of the polished rod load.

The reduction effects of these techniques also vary greatly. Side-flow pump can largely reduce the liquid pressure load by more than $50 \%$, but its reduction effect for the polished rod load is very limited. When a conventional pump is substituted by a side-flow pump, both maximum and minimum polished rod loads are decreased by around $4 \%$. Deep pumping with small-diameter pump only reduces the 
Table 7 Result of polished rod load calculation-deep pumping with small-diameter pump

\begin{tabular}{|c|c|c|c|c|c|c|c|c|}
\hline & \multicolumn{4}{|l|}{ Upstroke } & \multicolumn{4}{|l|}{ Downstroke } \\
\hline & $\begin{array}{l}\text { Sucker rod } \\
\text { gravity load/N }\end{array}$ & $\begin{array}{l}\text { Liquid } \\
\text { pressure load/ } \\
\mathrm{N}\end{array}$ & $\begin{array}{l}\text { Dynamic } \\
\operatorname{load} / \mathrm{N}\end{array}$ & $\begin{array}{l}\text { Maximum } \\
\text { polished rod load/ } \\
\mathrm{N}\end{array}$ & $\begin{array}{l}\text { Sucker rod } \\
\text { gravity load/N }\end{array}$ & $\begin{array}{l}\text { Liquid } \\
\text { pressure load/ } \\
\mathrm{N}\end{array}$ & $\begin{array}{l}\text { Dynamic } \\
\text { load/N }\end{array}$ & $\begin{array}{l}\text { Minimum } \\
\text { polished rod load/ } \\
\mathrm{N}\end{array}$ \\
\hline $\begin{array}{l}\text { D56 mm } \\
\text { pump }\end{array}$ & $222,290.5$ & $50,734.3$ & $17,877.3$ & $290,902.1$ & $222,290.5$ & $-15,953.1$ & $-20,625.5$ & $185,711.9$ \\
\hline $\begin{array}{l}\mathrm{D} 38 \mathrm{~mm} \\
\text { pump }\end{array}$ & $222,290.5$ & $14,753.7$ & $20,857.0$ & $257,901.2$ & $222,290.5$ & $-15,953.1$ & $-17,531.7$ & $188,805.7$ \\
\hline Reduction & 0 & $35,980.6$ & -2979.7 & $33,000.9$ & 0 & 0 & -3093.8 & -3093.8 \\
\hline $\begin{array}{l}\text { Reduction } \\
\text { rate }\end{array}$ & 0 & $71.0 \%$ & $-16.7 \%$ & $11.3 \%$ & 0 & 0 & $-15.0 \%$ & $-1.7 \%$ \\
\hline
\end{tabular}

liquid pressure load in upstroke, so only maximum polished rod load is decreased. The reduction effect depends on the size of the pump used. When a D56 $\mathrm{mm}$ pump is replaced by a D38 mm pump, the maximum polished rod load is decreased by about $11 \%$. Fiberglass sucker rod can greatly reduce the polished rod load in whole stroke by around $50 \%$. The reduction effect depends on the proportion of fiberglass sucker rod in a composite rod string. Rod load reducer creates a constant reduction force, which is determined by its installed depth and the depth of the working fluid level. In our case, both maximum and minimum polished rod loads are decreased by around $20 \%$.

Figure 5 shows that sucker rod gravity load is the predominant part of the polished rod load in deep wells. So in

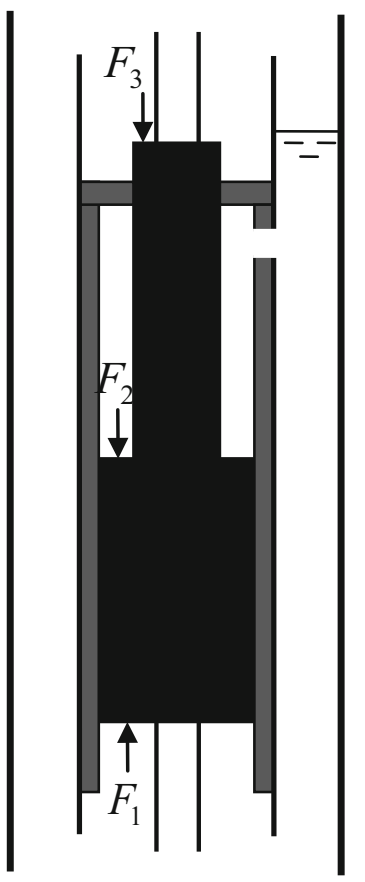

(a)

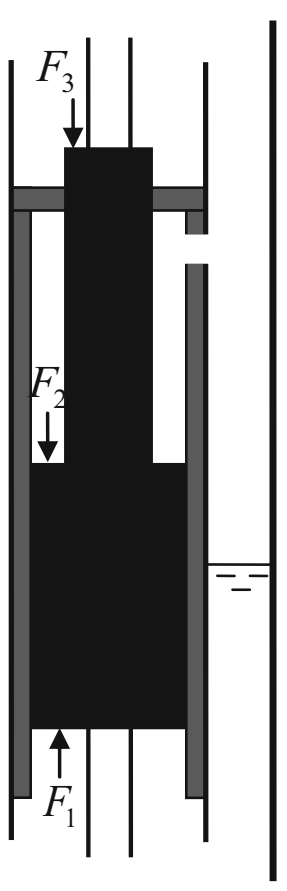

(b) order to reduce the polished rod load, changing sucker rod gravity load is more effective than changing liquid pressure load. Dynamic load which is a more complex part of the polished rod load only accounts for less than $10 \%$ and less sensitive to these rod load reduction techniques.

Every technique has its limitations and disadvantages which may cause certain problems when put into use. When a side-flow pump is applied, the resistance on the plunger caused by the liquid pressure would increase. This resistance may cause the sucker rod to bend in downstroke. This problem may be the reason why side-flow pump has not been widely used yet. Deep pumping with small-diameter pump needs to use a small pump in order to get a relatively good reduction effect; however, small pump is not suitable for high production wells. So its application is limited. In spite of various advantages for fiberglass-steel composite sucker rod such as low density, good corrosion resistance and good elasticity, limitations also exist for example low compression and bending resistance. It cannot be applied to high temperature, heavy oil and deviated wells. Rod load reducer may increase the energy consumption of the pumping system according to Cen et al. (2015).

\section{Conclusions}

Based on the above analysis, we can reach the following conclusions:Sucker rod gravity load is the predominant part of the polished rod load in deep wells. So in order to reduce the polished rod load, changing sucker rod gravity load is more effective than changing liquid pressure load.

Side-flow pump can largely reduce the liquid pressure load, but its reduction effect for the polished rod load is very limited. Deep pumping with small-diameter pump also reduces the liquid pressure load. On the contrary, fiberglass sucker rod can greatly reduce the polished rod load by decreasing the weight of the sucker rod. Rod load reducer does not change the previous load; instead, it can create an additional reduction force. Among them,

Fig. 4 Force analysis of rod load reducer 
Fig. 5 Composition of the maximum polished rod load
Maximum polished rod load -Conventional pump

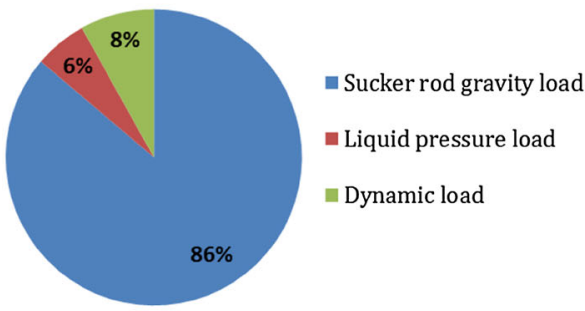

Maximum polished rod load -Bigger conventional pump

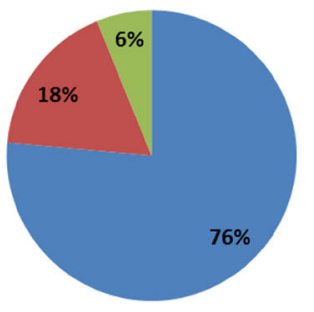

- Sucker rod gravity load

- Liquid pressure load

ఐ Dynamic load

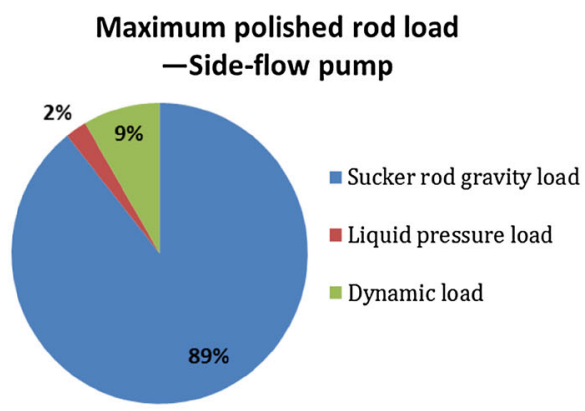

Maximum polished rod load -Fiberglass-steel mixed sucker rod

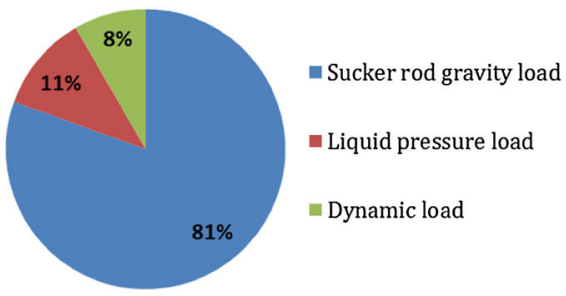

fiberglass sucker rod is the most effective rod load reduction technique.

When using a side-flow pump, the resistance on the plunger caused by the liquid pressure would increase. This resistance may cause the sucker rod to bend in downstroke. Deep pumping with small-diameter pump is not suitable for high production wells. Fiberglass-steel composite sucker rod cannot be applied to high temperature, heavy oil and deviated wells. Rod load reducer may increase the energy consumption of the pumping system. These limitations and disadvantages should be considered in practical application.

Open Access This article is distributed under the terms of the Creative Commons Attribution 4.0 International License (http:// creativecommons.org/licenses/by/4.0/), which permits unrestricted use, distribution, and reproduction in any medium, provided you give appropriate credit to the original author(s) and the source, provide a link to the Creative Commons license, and indicate if changes were made.

\section{References}

API RP 11L (1977) API recommended practice for design calculations for sucker rod pumping systems (conventional units) 3rd edn

Cen X, Wu X, Gao S (2015) Two techniques for reducing sucker-rod loads in deep wells. Chem Technol Fuels Oils 51(4):371-378
Feng YQ (1990) The application of deep pumping with smalldiameter pump and its associated technology. Oil Drill Prod Technol 8(2):63-68

Gibbs SG (1991) Application of fiberglass sucker rods. Society of Petroleum Engineers, Richardson. doi:10.2118/20151-PA

Hicks AW (1986) Using fiberglass sucker rods in deep wells. Society of petroleum engineers, Richardson. doi:10.2118/14974-MS

Li C (1991) Using API RP 11L recommended method to design fiberglass-steel composite sucker rod. Oil Field Equip 1:18-21

Luan G, He S, Yang Z, Zhao H, Hu J, Xie Q, Shen Y (2011) A prediction model for a new deep-rod pumping system. J Pet Sci Eng 80(1):75-80. doi:10.1016/j.petrol.2011.10.011 (ISSN 0920-4105)

Meng T, Yang JB, Han GH et al (2002) The application of Sc rod load reducer in Zhongyuan oilfield. China Pet Mach 30(8):49-51

Saul HE III, Detterick JA (1980) Utilization of fiberglass sucker rods. Society of Petroleum Engineers, Richardson. doi:10.2118/8246PA

Tan CD, Zhang SW (2005) Application and development of technology of wire rope sucker rod pumping system. Oil Field Equip 34(6):33-35

Zhao HY, Liu F, (2009) The application and research of deep pumping technology in TAHE oilfield. In: The 5th international symposium of oil and gas reservoir geology and exploitation. Oil and gas reservoir exploitation. Production and operations. Beijing, pp 919-917

Zhao R, Zhang X, Tao Z, Chen S, Zhang X, Li G et al (2016) The research and application of carbon fiber rods in deep oil wells of Xinjiang oilfield, china. Society of Petroleum Engineers, Richardson. doi:10.2118/184203-MS 